Social Dilemmas in Cancer Prevention 


\section{Social Dilemmas in \\ Cancer Prevention}

Edited by

\section{Basil A. Stoll}

Honorary Consulting Physician to Oncology Departments, St Thomas' Hospital and Royal Free Hospital, London

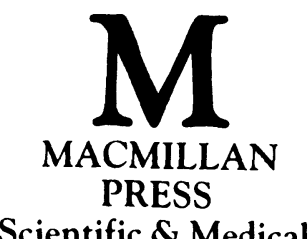

Scientific \& Medical 
(C) The Editor and the Contributors 1989

Softcover reprint of the hardcover 1st edition 1989

All rights reserved. No reproduction, copy or transmission of this publication may be made without written permission.

No paragraph of this publication may be reproduced, copied or transmitted save with written permission or in accordance with the provisions of the Copyright Act 1956 (as amended), or under the terms of any licence permitting limited copying issued by the Copyright Licensing Agency, 33-4 Alfred Place, London WC1E 7DP.

Any person who does any unauthorised act in relation to this publication may be liable to criminal prosecution and civil claims for damages.

First published 1989

Published by

THE MACMILLAN PRESS LTD

Houndmills, Basingstoke, Hampshire RG21 2XS

and London

Companies and representatives

throughout the world

British Library Cataloguing in Publication Data

Social dilemmas in cancer prevention

1. Man. Cancer. Prevention

I. Stoll, Basil A. (Basil Arnold)

$616.99^{\prime} 405$

ISBN 978-1-349-10710-0

ISBN 978-1-349-10708-7 (eBook)

DOI 10.1007/978-1-349-10708-7 


\section{Contents}

$\begin{array}{ll}\text { The Contributors } & \text { ix }\end{array}$

Preface $\quad$ xi

Introduction Basil A. Stoll 1

Part 1 Dilemmas in Strategies for the Community

$\begin{array}{lll}\text { 1. } & \text { Dilemmas in selecting a strategy } & 7\end{array}$

Basil A. Stoll

Introduction $\quad 7$

Regulating exposure to carcinogens $\quad 8$

Obstacles to cancer prevention 11

Dilemmas in primary prevention $\quad 14$

Dilemmas in cancer screening $\quad 15$

$\begin{array}{ll}\text { Primary prevention versus screening } & 17\end{array}$

$\begin{array}{ll}\text { Conclusion } & 18\end{array}$

2. Multiple factors in a multistep process 21

Basil A. Stoll

Introduction $\quad 21$

Definition of a carcinogen $\quad 21$

Multiple steps in progression to cancer 24

Susceptibility to carcinogens $\quad 26$

Changing patterns of cancer $\quad 27$

Conclusion $\quad 30$ 
3. Diet-related cancer and its control

Deirdre Haslett and John Kevany

Introduction

Dietary fats and fibre $\quad 33$

Micronutrients $\quad 34$

Naturally-occurring food constituents and contaminants 36

$\begin{array}{ll}\text { Food additives } & 37\end{array}$

Diet modification in the control of cancer 38

$\begin{array}{ll}\text { Conclusion } & 42\end{array}$

4. Leisure-related cancer and its control 45

J.A. Muir Gray

Introduction

Eating and sexual intercourse as leisure activities $\quad 45$

$\begin{array}{ll}\text { Wealth and leisure-related cancer } & 47\end{array}$

Health beliefs and leisure time choices $\quad 47$

$\begin{array}{ll}\text { Strategy for cancer prevention } & 50\end{array}$

Leisure as free time $\quad 52$

The role of the state $\quad 53$

$\begin{array}{ll}\text { Conclusion } & 54\end{array}$

5. How important is radiation in cancer risk? 57

Marc Edwards and William Hendee

Introduction

Sources and levels of low level ionizing radiation 58

Cancer risks from low level ionizing radiation 61

Sources and levels of non-ionizing radiation $\quad 62$

$\begin{array}{ll}\text { Cancer risks of non-ionizing radiation } & 63\end{array}$

Prospects for prevention of radiation-related cancer 64

$\begin{array}{ll}\text { Conclusion } & 65\end{array}$

6. Mass cancer screening in women; more harm than benefit? 67

Petr Skrabanek

Introduction

$\begin{array}{ll}\text { Breast cancer screening } & 68\end{array}$

$\begin{array}{ll}\text { Cervical cancer screening } & 70\end{array}$

$\begin{array}{ll}\text { Ethical aspects of screening } & 72\end{array}$

$\begin{array}{ll}\text { Conclusion } & 72\end{array}$ 
Part 2. Dilemmas in Strategies for the Individual

7. Risk from heredity, race and family

Bernadette Herity

Introduction

$\begin{array}{ll}\text { Heredity versus environment } & 78\end{array}$

$\begin{array}{ll}\text { Genetic susceptibility to cancer } & 78\end{array}$

$\begin{array}{ll}\text { Genetic and environmental interaction } & 81\end{array}$

Familial cancer - dilemmas in prevention $\quad 85$

$\begin{array}{lr}\text { Practical preventive measures } & 87\end{array}$

$\begin{array}{lr}\text { Conclusion } & 89\end{array}$

8. Risk from social class and occupation $\quad 91$

Michael Calnan

$\begin{array}{ll}\text { Introduction } & 91\end{array}$

$\begin{array}{ll}\text { Explaining the social class effect } & 93\end{array}$

$\begin{array}{lr}\text { Life style or working environment? } & 95\end{array}$

$\begin{array}{lr}\text { Social class and health education } & 100\end{array}$

$\begin{array}{ll}\text { Conclusion } & 101\end{array}$

9. Does the mind affect cancer risk? 103

Basil A. Stoll

$\begin{array}{ll}\text { Introduction } & 103\end{array}$

Are some personalities prone to cancer? $\quad 104$

$\begin{array}{ll}\text { Can life events predispose to cancer? } & 107\end{array}$

$\begin{array}{ll}\text { Depression and hopelessness as possible precursors } & 108\end{array}$

$\begin{array}{ll}\text { Possible mechanisms involved } & 109\end{array}$

$\begin{array}{ll}\text { Experimental evidence } & 112\end{array}$

$\begin{array}{ll}\text { Conclusion } & 113\end{array}$

10. What makes for high risk to cancer? 115

Basil A. Stoll

$\begin{array}{ll}\text { Introduction } & 115\end{array}$

$\begin{array}{ll}\text { Identifying susceptible individuals } & 115\end{array}$

$\begin{array}{ll}\text { Age and gender factors } & 116\end{array}$

$\begin{array}{ll}\text { Genetic and familial factors } & 118\end{array}$

$\begin{array}{ll}\text { Impaired immunity } & 119\end{array}$

$\begin{array}{ll}\text { Environmental factors } & 120\end{array}$ 
Second primary cancers

Conclusion

11. Strategies for chemical prevention of cancer

Daniel W. Nixon

Introduction

125

Scope and mechanisms of chemoprevention

Chemopreventive agent development

Clinical trials of chemoprevention

129

Dilemmas in setting up clinical trials

130

Conclusion

131

Index

133 


\section{The Contributors}

Michael Calnan, MSc, PhD

Senior Research Fellow, Health Services Research Unit, University of Kent at Canterbury, UK

\section{Marc Edwards, PhD}

Radiological Physicist, St. Luke's Hospital, Kansas City; Adjunct Associate Professor of Radiology, University of Missouri, Kansas City, USA

\section{J.A. Muir Gray, MD, FRCP (Glas), MRCP, FFCM}

Community Physician, District

Department of Community Medicine, Radcliffe Infirmary, Oxford, UK

Deidre Haslett, PhD, MSc

Research Fellow, Department of Community Health, Trinity College, Dublin University, Ireland

\section{William R. Hendee, PhD}

Vice President of Science and Technology, American Medical Association; Adjunct Associate Professor of Radiology, Northwest University School of Medicine; Clinical Professor of Radiology and Biophysics, Medical College of Wisconsin, USA

\section{Bernadette Herity, MD, DPH, FFCMI}

Lecturer, Department of Community

Medicine and Epidemiology,

University College, Dublin, Ireland

John Kevany, MB, MPH, FFCM Associate Professor of Community Health, Faculty of Health Sciences, Trinity College, Dublin University, Ireland

Daniel W. Nixon, MD

Associate Director, Cancer Prevention Research Program, Division of Cancer Prevention and Control, National Institutes of Health, Bethesda, Maryland, USA

Petr Skrabanek, PhD

Lecturer in Community Health, Trinity College, University of Dublin, Dublin, Ireland

\section{Basil A. Stoll, FRCR, FFR}

Honorary Consulting Physician to Oncology Department, St. Thomas' Hospital, and to Oncology Department Royal Free Hospital, London, UK 


\section{Preface}

My intentions for this book are that it should provide an arena for frank debate on the clash between government paternalism and the autonomy of the individual as applied to cancer prevention in the community. The debate involves not only the doctors, nurses, psychologists and other professionals involved in the day-to-day care of cancer patients and educating the public, but also epidemiologists, sociologists and health economists who are concerned with strategies for controlling and preventing cancer in the community.

Contributors are drawn from both sides of the Atlantic in order to emphasise contrasts in the attitudes of different types of society in the West. The participating authors have written in clear language and avoided jargon because the topics discussed are of vital interest not only to health professionals but also to professionals from a variety of disciplines and even lay readers. As a result, no specialist knowledge is required to understand the discussion and the contents of each book are planned so that they can easily be read from cover to cover.

This book also has a wider context when considered alongside two other titles I have had published: Cost versus Benefit in Cancer Care and Ethical Dilemmas in Cancer Care.

These books debate the most cost effective use of limited health resources, and the need for guidelines to cover serious ethical problems in the management of the cancer patient, respectively. The underlying theme of all three books is the need to train health professionals in the art of responding to people's human needs as opposed to the science of managing their disease.

It is hoped that correction of misconceptions, clarification of inconsistent thinking and exposure of controversial issues will lead to better management of the medical, personal and social problems involved in 
fighting cancer. At the very least, the obstacles standing in our way will become clearer.

I would like to thank all the contributors for the way in which they have responded to the challenge of the book. I have been persuaded to permit slight overlap between chapters in some places in order that each chapter shall be complete in itself.

London, 1989

B.A.S. 